Article

\title{
Transcriptome Analysis of C. elegans Reveals Novel Targets for DON Cytotoxicity
}

\author{
Rong Di, Hanzhong Zhang and Michael A. Lawton*
}

Department of Plant Biology, Rutgers, The State University of New Jersey, New Brunswick, NJ 08901, USA; rongdi@sebs.rutgers.edu (R.D.); hzhang1234@aol.com (H.Z.)

* Correspondence: malawton@sebs.rutgers.edu; Tel.: +1-848-932-6166

Received: 28 April 2018; Accepted: 25 June 2018; Published: 27 June 2018

\begin{abstract}
Deoxynivalenol (DON) is a mycotoxin produced by Fusarium spp. that causes Fusarium head blight (FHB) disease in cereal crops. Ingestion of food contaminated with DON poses serious human health complications. However, the DON cytotoxicity has been mostly deduced from animal studies. In this study, we used the nematode Caenorhabditis elegans (C. elegans) as a tractable animal model to dissect the toxic effect of DON. Our results indicate that DON reduces the fecundity and lifespan of $C$. elegans. Real-time quantitative polymerase chain reaction (RT-qPCR) analysis showed that DON upregulates innate immunity-related genes including C17H12.8 and K08D8.5 encoding PMK-1 (mitogen activated protein kinase-1)-regulated immune effectors, and F35E12.5 encoding a CUB-like domain-containing protein. Furthermore, our RNAseq data demonstrate that out of $\sim 17,000$ C. elegans genes, 313 are upregulated and 166 were downregulated by DON treatment. Among the DON-upregulated genes, several are ugt genes encoding UDP-glucuronosyl transferase (UGTs) which are known to be involved in chemical detoxification. The three upregulated genes, F52F10.4 (oac-32), C10H11.6 (ugt-26) and C10H11.4 (ugt-28) encoding the O-acyltransferase homolog, UGT26 and UGT 28, respectively, are shown to contribute to DON tolerance by a RNAi bacterial feeding experiment. The results of this study provide insights to the targets of DON cytotoxicity and potential mitigation measures.
\end{abstract}

Keywords: Fusarium head blight; deoxynivalenol; cytotoxicity; Caenorhabditis elegans; RNAseq

Key Contribution: RNAseq analysis was conducted on DON-intoxicated C. elegans.

\section{Introduction}

Deoxynivalenol (DON), a trichothecene mycotoxin, is produced by species of the fungus Fusarium which is responsible for causing Fusarium head blight (FHB) disease in wheat, barley, maize, oats, rye and rice worldwide [1,2]. Fusarium spp. infection of plants results in both yield loss and the contamination of grain with mycotoxins. It has been shown that acute exposure of experimental animals to extremely high doses $(\geq 27 \mathrm{mg} / \mathrm{kg}$ body weight) of DON in diets causes mortality or marked tissue injury, whereas acute exposure to relatively low doses ( $\geq 50 \mathrm{~g} / \mathrm{kg}$ body weight) induces vomiting in the most sensitive pigs [3]. Chronic exposure of pigs to $2 \mathrm{ppm}$ of DON impairs weight gain and disrupts immune functions [3].

As reviewed by Pestka [4], the mechanisms of DON cytotoxicity mainly involve the modulation of the innate immune systems by interacting with ribosomes, activating double-stranded RNA-associated protein kinase (PKR), inhibiting translation, evoking endoplasmic reticulum (ER) stress responses and elevating the expression of proinflammatory genes. Most of the known toxic effects of DON and its cytotoxic mechanisms have been studied in experimental animals such as pigs [3] and mice [5]. Besides a limited number of epidemiological studies, DON cytotoxicity in humans has been deduced 
mainly from studies performed in animals [2]. Since pigs have been used as a model to study human intestines [6] and drug-induced emesis [7], it has been suggested that people may be as sensitive to DON as are pigs, with a vomiting threshold of 50-100 g/ kg body weight [2]. Nonetheless, significant questions remain regarding the cytotoxic mechanisms of DON in humans and the mitigation strategies that might counter its effects.

The nematode Caenorhabditis elegans (C. elegans) is a popular model organism for genetic and developmental studies owing to its sequenced genome, well-defined cell lineage, the availability of an extensive knockout mutant library, and the high degree conservation of gene functions and signal transduction pathways with humans [8]. It has also been used as an invertebrate model for toxicological studies for heavy metals [9], new chemicals [10] and known toxicants such as paraquat and parathion [11]. C. elegans was first used in 2011 to show that the brood size and developmental rate of C. elegans were significantly affected when exposed to 500 and $1000 \mathrm{~g} / \mathrm{mL}$ of DON [12]. The toxic effects of DON on the growth, reproduction and lifespan of C. elegans were further studied recently [13]. However, the precise mechanisms of DON cytotoxicity in C. elegans remain unclear.

In order to understand the overall toxic effects of DON in C. elegans, we employed RNAseq to analyze the comprehensive modulation of gene expression in C. elegans upon DON intoxication. RNAseq analysis has been used to elucidate transcriptional changes following manganese exposure in C. elegans [14]. Whole genome microarray analysis has similarly been used to profile the host response in mouse brain following exposure to the plant toxin abrin [15]. Our results indicate that exposure of $C$. elegans to DON led to the upregulation of genes involved in innate immunity and the downregulation of structural and housekeeping genes. These data provide the molecular foundation for developing a better understanding of the mechanisms of DON toxicity in the C. elegans model and for identifying possible targets for the intervention and amelioration of DON toxicity in animals and humans.

\section{Results}

\subsection{Deoxynivalenol (DON) Reduces Fecundity and Lifespan of C. elegans}

Synchronized wild type N2 worms at the L2 stage were exposed to 125, 250 and $500 \mu \mathrm{g} / \mathrm{mL}$ DON for $24 \mathrm{~h}$. Exposure to 250 and $500 \mu \mathrm{g} / \mathrm{mL}$ DON reduced viability rate of N2 worms from 100\% to 95-98\%, while exposure to $125 \mu \mathrm{g} / \mathrm{mL}$ DON had no effect. Although there was only a minor effect on L2 stage worm viability, exposure to DON resulted in a marked reduction in fecundity. Transfer of L4 stage worms to nematode growth medium (NGM) showed that DON exposure significantly $(p<0.001)$ reduced the number of eggs produced $24 \mathrm{~h}$ later by $36.7 \%, 72.0 \%$ and $92.7 \%$, respectively (Figure 1 ). Worms exposed to DON in $0.6 \%$ dimethyl sulfoxide (DMSO) only were placed onto NGM medium containing $0.1 \mathrm{mg} / \mathrm{mL}$ 5-fluorodeoxyuridine (FUDR) to prevent production of additional progeny, allowing the effect of DON toxicity on the worm's lifespan to be observed (Figure 2). Treatment of worms with $500 \mu \mathrm{g} / \mathrm{mL}$ DON resulted in 100\% mortality at 11 days post treatment (dpt), whereas worms treated with only $0.6 \%$ DMSO (control sample) took until $13 \mathrm{dpt}$ to reach $100 \%$ mortality. At $11 \mathrm{dpt}$, the mortality rate for worms treated with 250 and $125 \mu \mathrm{g} / \mathrm{mL}$ DON were $98 \%$ and 90\%, respectively. It took 11.5 days to result in 50\% mortality for the $0.6 \%$ DMSO-fed worms, however, only 8.5, 9.0 and 9.5 days were needed, respectively, for the 500, 250 and $125 \mu \mathrm{g} / \mathrm{mL}$ DON-treated worms to reach $50 \%$ mortality (Figure 2 ). 


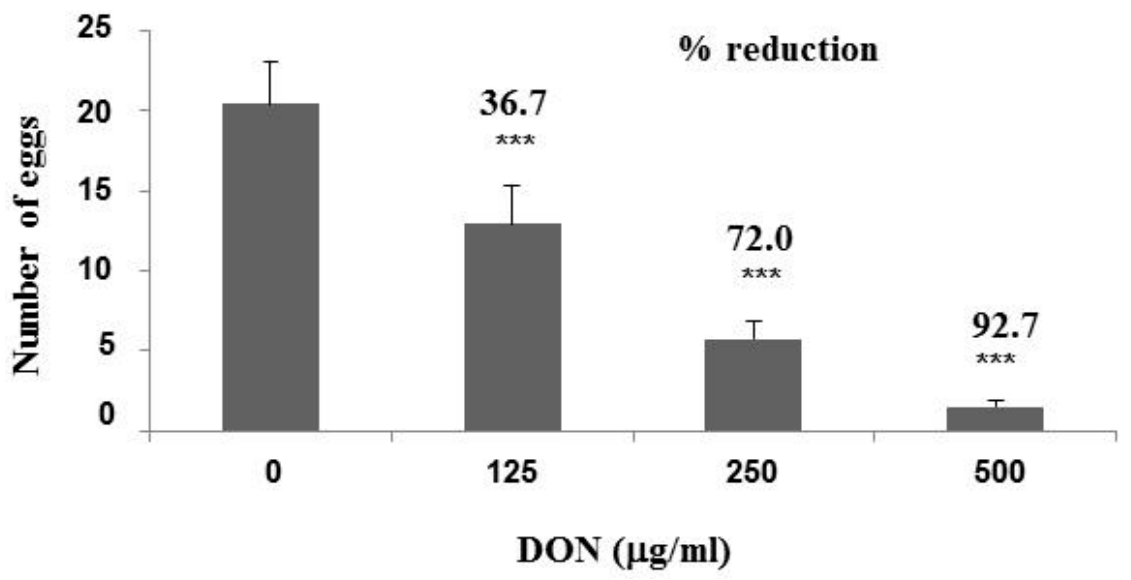

Figure 1. Effect of deoxynivalenol (DON) toxicity on egg-laying. N2 worms at the L2 stage were treated with the indicated concentrations of DON for $24 \mathrm{~h}$. After transfer onto nematode growth medium (NGM) without DON, they were allowed to lay eggs for $24 \mathrm{~h}$. Egg number was counted from at least 30 individual worms in each treatment and averaged from three independent experiments. Student's $t$-test was used to analyze the significant difference $(* * *, p<0.001)$ among treatments.

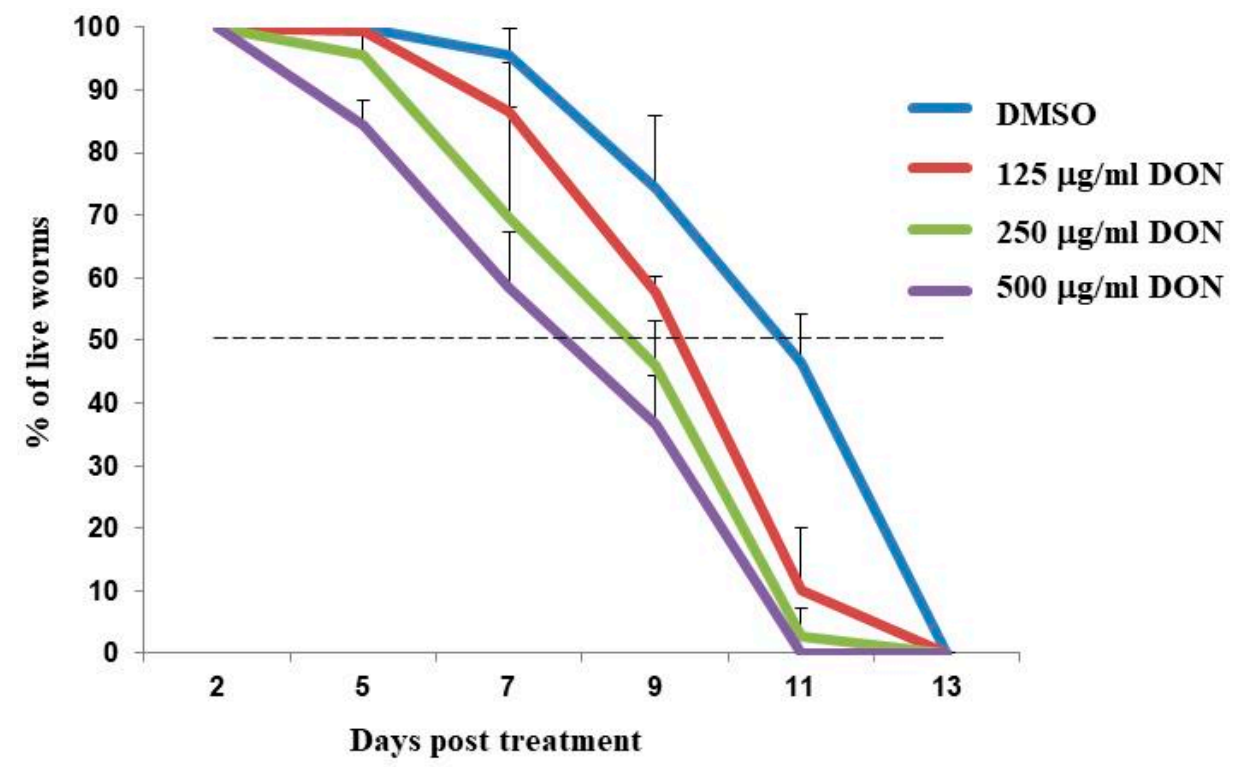

Figure 2. Effect of DON toxicity on lifespan. N2 worms at L2 stage were treated with 125, 250 and $500 \mu \mathrm{g} / \mathrm{mL}$ DON for $24 \mathrm{~h}$. After placing L4 worms on NGM medium containing $0.1 \mathrm{mg} / \mathrm{mL}$ 5-fluorodeoxyuridine (FUDR), the worms' viability was recorded every two days.

\subsection{DON Upregulates Genes Involved in Innate Immunity in C. elegans}

We examined DON-induced changes in mRNA levels of specific transcripts that were previously shown to be induced following exposure to bacterial pathogens [16]. Expression of the genes C17H12.8 and K08D8.5, encoding PMK-1 (mitogen activated protein kinase-1)-regulated immune effectors, are upregulated after is exposed to Pseudomonas aerugunosa strain PA14 [16] and to Shiga toxin-producing enterohaemorrhagic Escherichia coli (E. coli) strain EDL933 [17]. We initially studied whether DON also induces expression of these two genes, as well two other genes involved in innate immunity (R03G5.2, which encodes sek-1 and functions in activation of MAPK activity [17]; and F35E12.5, which encodes a CUB-like domain-containing protein) [18]. Treatment with the alkaloid compound harmane has been shown to upregulate F35E12 expression by approximately 8-fold during E. coli EDL933 infection and extend lifespan of [18]. 
C. elegans worms at L2 stage were treated with 125, 250 and $500 \mu \mathrm{g} / \mathrm{mL}$ DON for $24 \mathrm{~h}$. Real-time quantitative polymerase chain reaction (RT-qPCR) analysis using total worm RNA as template and gene-specific primers (Table 1) showed that R03G5.2 gene expression was not affected by DON treatment. However, the mRNA levels of C17H12.8, K08D8.5 and F35E12.5 were substantially upregulated by DON. Figure 3 shows that expression of the C17H12.8 gene increased in a dose-dependent manner by 16.9-, 30.3- and 35.3-fold when C. elegans was exposed to 125, 250 and $500 \mu \mathrm{g} / \mathrm{mL}$ DON, respectively, compared to comparable treatment with $0.6 \%$ DMSO. F35E12.5 gene expression increased by 12.2-, 17.4- and 16.7-fold when worms were, respectively, exposed to 125,250 and $500 \mu \mathrm{g} / \mathrm{mL}$ DON. Gene expression of $K 0.8 \Delta 8.5$ was also induced but less substantially, compared to C17H12.8 and F35E12.5, with 5.2-, 8.2- and 11.1-fold increases following the exposure of worms to 125,250 and $500 \mu \mathrm{g} / \mathrm{mL}$ DON, respectively.

Table 1. Gene-specific primers used in real-time quantitative polymerase chain reaction (RT-qPCR) analysis $\left(5^{\prime}-\right.$ to $\left.-3^{\prime}\right)$.

\begin{tabular}{ccc}
\hline Gene & Forward Primer & Reverse Primer \\
\hline C17H12.8 & GGCTCCTTGCACTTGTCACA & ATGATTGGCTCAGGGATCTGA \\
K08D8.5 & CCGGGAAGTCGAATGAACAT & GATGCAACACCTGCCAAAGA \\
F35E12.5 & CGCAGTTCAGTTGCCCATT & GGGATTGATCCAGACATTCCA \\
T04C12.6.2 & CTCCACGCGCCGTGTT & CATACCGACCATGACTCCTTGA \\
\hline
\end{tabular}

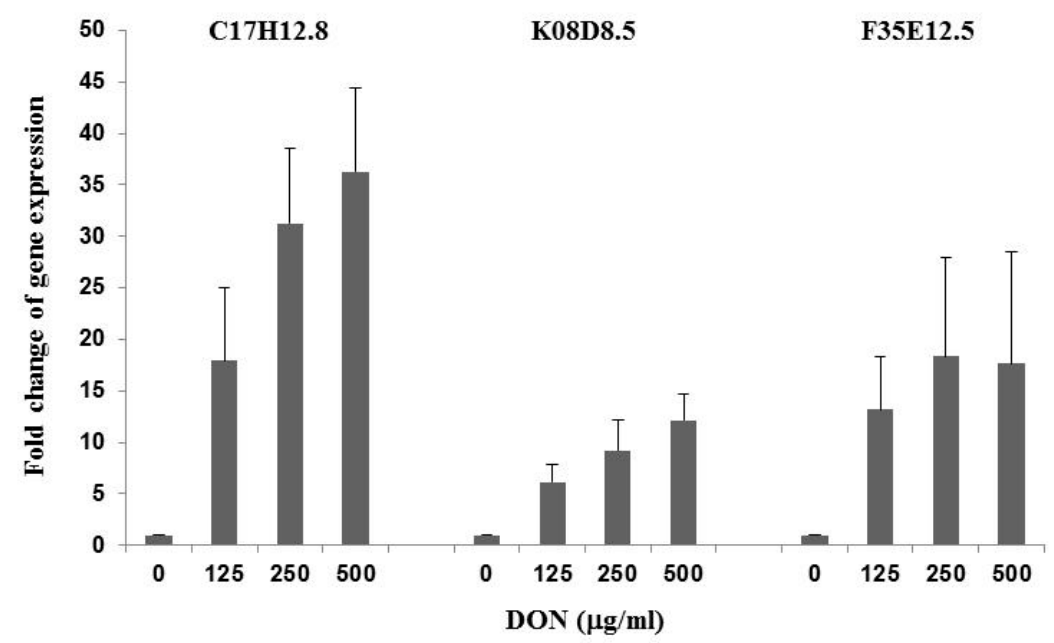

Figure 3. Upregulation of innate immunity-related genes in by DON. Real-time RT-qPCR analysis was conducted after worms were treated for $24 \mathrm{~h}$ with different levels of DON. Gene expression levels were compared to worms treated with $0.6 \%$ dimethyl sulfoxide (DMSO) by the $2^{-\Delta \Delta C t}$ relative quantification method. Actin 1 (T04C12.6.2) was used as the endogenous control gene.

\subsection{Gene Global Expression is Modulated by DON in RNAseq Analysis}

To investigate whether DON affects the expression of additional genes involved in innate immunity as well as genes associated with other cellular functions, we treated the L2 worms with either $250 \mu \mathrm{g} / \mathrm{mL}$ DON or $0.6 \%$ DMSO (as control) for $24 \mathrm{~h}$, extracted total RNA from each sample and characterized by RNAseq (performed by BGI). Following RNAseq analysis and gene annotation, gene expression levels from technical replicate samples were analyzed and averaged. As shown by the scatter plot of differentially expressed genes (DEGs) (Figure 4), out of $\sim 17,000$ genes, 313 genes were upregulated and 166 genes were downregulated by DON treatment. Table 2 lists 43 genes upregulated by more than 10 -fold and the ten genes downregulated by more than 10 -fold. The complete RNAseq data for all genes of $C$. elegans are included in Table S1. 


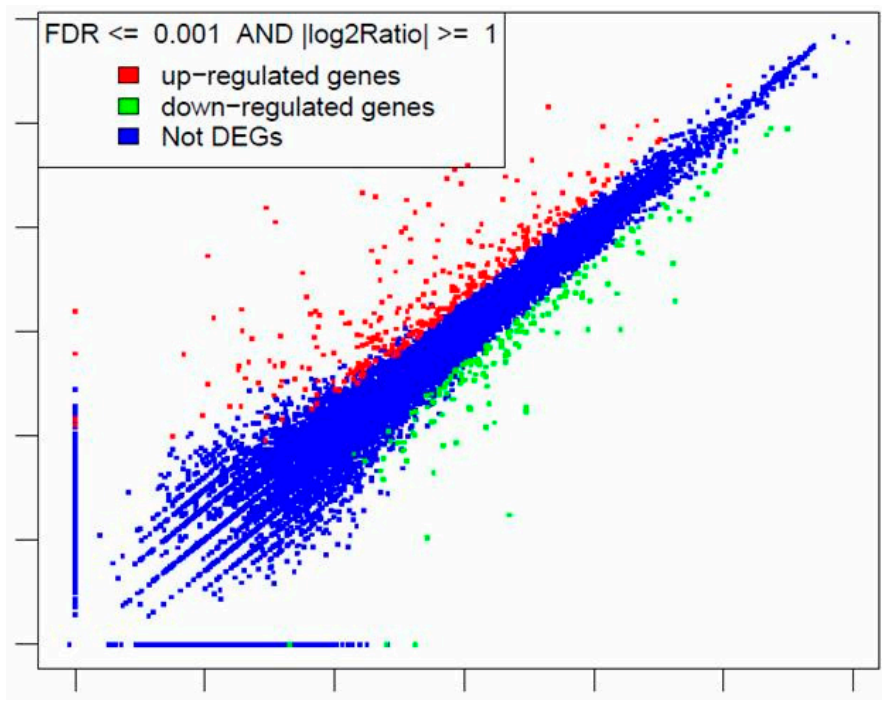

Figure 4. Scatter plot of differentially expressed genes in after treatment with $250 \mu \mathrm{g} / \mathrm{mL}$ DON for 24 h. Gene expression was analyzed by RNAseq.

Table 2. Genes that were up- $(+)$ or down- (-) regulated by more than 10 -fold in response to treatment with $250 \mu \mathrm{g} / \mathrm{mL}$ DON for $24 \mathrm{~h}$.

\begin{tabular}{|c|c|c|c|}
\hline Gene Symbol & Gene Name by WormBase & Gene Function by WormBase & $\begin{array}{l}\text { Fold Change of } \\
\text { Gene Expression }\end{array}$ \\
\hline F11D11.3 & F11D11.3 gene & unknown & $612.6+$ \\
\hline F52F10.4 & oac-32 (o-acyltransferase homolog) & transferase activity, transferring acyl & $513.4+$ \\
\hline H23L24.5 & $\begin{array}{l}\text { pme-4 [poly(ADP-ribose) } \\
\text { metabolism enzyme] }\end{array}$ & $\begin{array}{l}\text { poly(ADP-ribose) glycohydrolase } \\
\text { activity }\end{array}$ & $501.6+$ \\
\hline C07G3.2 & irg-1 (infection response gene) & $\begin{array}{l}\text { defense response to Gram-negative } \\
\text { bacterium, innate immune response }\end{array}$ & $94.5+$ \\
\hline F25A2.1 & F25A2.1 gene & triglyceride lipase activity & $52.0+$ \\
\hline Y39G10AR.6 & $\begin{array}{l}\text { ugt-31 (UDP-glucuronosyl } \\
\text { transferase) }\end{array}$ & $\begin{array}{l}\text { transferase activity, transferring hexosyl } \\
\text { groups }\end{array}$ & $39.5+$ \\
\hline$T 24 A 6.7$ & T24A6.7 gene & unknown & $37.2+$ \\
\hline C1OH11.6 & $\begin{array}{l}\text { ugt-26 (UDP-glucuronosyl } \\
\text { transferase) }\end{array}$ & $\begin{array}{l}\text { transferase activity, transferring hexosyl } \\
\text { groups }\end{array}$ & $37.1+$ \\
\hline Y $49 C 4 A .8$ & $\begin{array}{l}\text { ugt-29 (UDP-glucuronosyl } \\
\text { transferase) }\end{array}$ & $\begin{array}{l}\text { transferase activity, transferring hexosyl } \\
\text { groups }\end{array}$ & $33.1+$ \\
\hline C17H12.8 & C17H12.8 gene & $\begin{array}{l}\text { PMK-1-regulated gene in innate } \\
\text { immunity }\end{array}$ & $32.4+$ \\
\hline T16G1.5 & T16G1.5 gene & $\begin{array}{l}\text { transferase activity, transferring } \\
\text { phosphorus-containing groups }\end{array}$ & $28.2+$ \\
\hline $\mathrm{C} 10 \mathrm{H} 11.4$ & $\begin{array}{l}\text { ugt-28 (UDP-glucuronosyl } \\
\text { transferase) }\end{array}$ & $\begin{array}{c}\text { transferase activity, transferring hexosyl } \\
\text { groups }\end{array}$ & $27.8+$ \\
\hline F08F3.7 & $\begin{array}{l}\text { cyp-14A5 (cytochrome P450 } \\
\text { family) }\end{array}$ & $\begin{array}{l}\text { heme binding, iron ion binding, } \\
\text { oxidoreductase activity }\end{array}$ & $27.7+$ \\
\hline Y58A7A.5 & Y58A7A.5 gene & unknown & $26.7+$ \\
\hline$Y 26 D 4 A .21$ & Y26D4A.21 gene & unknown & $25.5+$ \\
\hline C49G7.7 & C49G7.7 gene & unknown & $23.7+$ \\
\hline Y39A3B.7 & Y39A3B.7 gene & unknown & $23.5+$ \\
\hline T05F1.9 & T05F1.9 gene & unknown & $23.3+$ \\
\hline F45E4.1 & $\begin{array}{l}\text { arf-1.1 (ADP-ribosylation factor } \\
\text { related) }\end{array}$ & GTP binding & $22.4+$ \\
\hline F14F9.3 & F14F9.3 gene & zinc ion binding & $21.8+$ \\
\hline
\end{tabular}


Table 2. Cont.

\begin{tabular}{|c|c|c|c|}
\hline Gene Symbol & Gene Name by WormBase & Gene Function by WormBase & $\begin{array}{l}\text { Fold Change of } \\
\text { Gene Expression }\end{array}$ \\
\hline C06B3.7 & C06B3.7 gene & unknown & $21.5+$ \\
\hline F14F9.4 & F14F9.4 gene & zinc ion binding & $20.1+$ \\
\hline F22E10.1 & \multirow{2}{*}{$\begin{array}{c}p g p-12 \text { (P-glycoprotein related) } \\
s d z-35 \text { (SKN-1 dependent zygotic } \\
\text { transcript) }\end{array}$} & ATP binding, ATPase activity & $18.9+$ \\
\hline ZC239.12 & & protein binding & $17.3+$ \\
\hline C32H11.1 & $\begin{array}{c}\text { C32H11.1 gene } \\
\text { (encoding a CUB-like domain } \\
\text { containing protine) }\end{array}$ & $\begin{array}{l}\text { innate immune response to several } \\
\text { different bacterial pathogens }\end{array}$ & $17.3+$ \\
\hline F14F9.2 & F14F9.2 gene & unknown & $16.7+$ \\
\hline Y119D3A.3 & fbxa-35 (F-box A protein) & protein binding & $16.3+$ \\
\hline$Z K 228.4$ & ZK228.4 gene & unknown & $15.5+$ \\
\hline F56D6.2 & clec-67 (C-type lectin) & carbohydrate binding & $14.9+$ \\
\hline F33H12.7 & F33H12.7 gene & unknown & $14.7+$ \\
\hline F55G11.5 & $\begin{array}{l}\text { dod-22 (nownstream of DAF-16, } \\
\text { regulated by DAF-16) }\end{array}$ & $\begin{array}{l}\text { defense response to Gram-negative } \\
\text { bacterium, innate immune response }\end{array}$ & $13.9+$ \\
\hline F14H8.6 & $\begin{array}{c}\text { cng-1 (cyclic nucleotide gated } \\
\text { channel) }\end{array}$ & ion transmembrane transporter activity & $13.7+$ \\
\hline C49G7.5 & irg-2 (infection response gene) & $\begin{array}{l}\text { defense response to Gram-negative } \\
\text { bacterium, innate immune response }\end{array}$ & $13.3+$ \\
\hline K11D12.5 & $\begin{array}{c}\text { swt-7 (SWEET sugar transporter } \\
\text { family) }\end{array}$ & defense response & $13.2+$ \\
\hline$Y 58 A 7 A .3$ & Y58A7A.3 gene & zinc ion binding & $12.8+$ \\
\hline$F 43 C 1.7$ & F43C1.7 gene & unknown & $12.7+$ \\
\hline C17H12.6 & C17H12.6 gene & unknown & $12.2+$ \\
\hline F08E10.7 & $\begin{array}{l}\text { scl-24 (SCP-like extracellular } \\
\text { protein) }\end{array}$ & unknown & $12.2+$ \\
\hline F36G9.12 & oac-20 (o-acyltransferase homolog) & $\begin{array}{l}\text { transferase activity, transferring acyl } \\
\text { groups other than amino-acyl groups }\end{array}$ & $12.2+$ \\
\hline Y37H2A.14 & Y37H2A.14 gene & unknown & $12.1+$ \\
\hline K08D8.5 & $\begin{array}{c}\text { K08D8.5 gene } \\
\text { (encoding a CUB-like domain } \\
\text { containing protine) }\end{array}$ & $\begin{array}{l}\text { innate immune response to several } \\
\text { different bacterial pathogens }\end{array}$ & $12.0+$ \\
\hline F35E12.5 & F35E12.5 gene & unknown & $11.8+$ \\
\hline F54D5.4 & F54D5.4 gene & unknown & $10.9+$ \\
\hline T05B4.8 & T05B4.8 gene & unknown & $10.2+$ \\
\hline W05G11.3 & col-88 (collagen) & structural constituent of cuticle & 415.8 \\
\hline $\mathrm{T} 26 \mathrm{H} 2.5$ & sqst-3 (SeQueSTosome related) & zinc ion binding & $250.4-$ \\
\hline C42D8.2 & $\begin{array}{l}\text { vit-2 (vitellogenin structural } \\
\text { genes) (yolk protein genes) }\end{array}$ & lipid transporter activity & $44.7-$ \\
\hline C45G7.3 & ilys-3 (invertebrate lysozyme) & lysozyme activity & $21.3-$ \\
\hline F41F3.4 & col-139 (collagen) & structural constituent of cuticle & $17.7-$ \\
\hline M18.1 & col-129 (collagen) & structural constituent of cuticle & $16.4-$ \\
\hline B0218.8 & clec-52 (C-type lectin) & carbohydrate binding & $15.4-$ \\
\hline ZK1193.1 & col-19 (collagen) & structural constituent of cuticle & $12.9-$ \\
\hline C36A4.1 & $\begin{array}{c}\text { cyp-25A1 (cytochrome P450 } \\
\text { family) }\end{array}$ & $\begin{array}{l}\text { heme-binding, iron ion binding, } \\
\text { oxidoreductase activity }\end{array}$ & $12.8-$ \\
\hline F26F12.1 & col-140 (collagen) & structural constituent of cuticle & $12.1-$ \\
\hline
\end{tabular}

Table 2 shows that the expression of $C 17 H 12.8, K 08 D 8.5$ and F35E12.8, three genes involved in innate immunity, increased, respectively, 32.4-, 12.0- and 11.8-fold as shown by RNAseq analysis and 30.3-, 8.2- and 17.4-fold as shown by RT-qPCR assay performed on a separate batch of treated 
worms (Figure 3). Additionally, both RNAseq and RT-qPCR analysis showed that the R03G5.2 (sek-1) gene expression was not affected by $250 \mu \mathrm{g} / \mathrm{mL}$ DON treatment. These comparative data provide support for the validity of the RNAseq results for genes whose expression has not been previously validated by RT-qPCR.

The C. elegans database WormBase (WormBase.org) shows that the genome contains 66 ugt genes encoding UDP-glucuronosyl transferase (UGT). UGTs are involved in chemical detoxification and are present in organisms of all the major kingdoms [19]. The RNAseq results indicate that the C. elegans ugt-31, ugt-26, ugt-29 and ugt-28 gene expression was upregulated by DON by 39.5-, 37.1-, 33.1and 27.8-fold respectively (Table 2). Additionally, the RNAseq results showed that the expression of ugt-16, ugt-24, ugt-48, ugt-19, ugt-62 and ugt-1 genes were increased by 6.2-, 5.5-, 4.8-, 4.4-, 4.1and 2.6-fold, respectively, upon DON treatment.

Our RNAseq data also indicate that 10 genes were downregulated at least 10-fold upon DON treatment, including four genes encoding collagen (Table 2).

\subsection{Functional Analysis of DON-Induced Genes in Conferring DON Tolerance}

We used an RNAi suppression assay to assess the functional contributions of DON-induced genes to the ability of worms to cope with exposure to DON. We chose three genes belonging to the group whose expression was most highly upregulated by DON intoxication (Table 2). RNAi-expressing bacteria, obtained from Open Biosystems, were fed to worms and used to suppress the expression of: F52F10.4 (oac-32) encoding the O-acyltransferase homolog, C10H11.6 (ugt-26) encoding UDP-glucuronosyl transferase 26 and C10H11.4 (ugt-28) encoding UDP-glucuronosyl transferase 28. Synchronized eggs were placed on NGM plates seeded with either OP50 bacteria or oac-32, ugt-26 and ugt-28 RNAi bacteria, and the worms were grown for $24 \mathrm{~h}$. The L2 worms (around 50 for each treatment) were then treated with $250 \mu \mathrm{g} / \mathrm{mL}$ DON in S-medium supplemented with OP50 or oac-32, ugt-26 or ugt-28 RNAi bacteria for $24 \mathrm{~h}$. This experiment was repeated three times, standard errors were expressed as " \pm ". As a control, L2 worms were cultured in S-medium lacking DON and exposed to either OP50, oac-32, ugt-26 or ugt-28 RNAi bacteria for $24 \mathrm{~h}$. There was no viability reduction in the worms cultured with oac-32, ugt-26 or ugt-28 RNAi bacteria, compared to those cultured in OP50 (data not shown), indicating that suppression of these genes has no effect on the normal lifespan of worms. Counting the number of live worms (at L4 stage now) at the end of DON treatment showed that worm viability was reduced to $89.3 \% \pm 8.1 \%(p=0.04), 84.3 \% \pm 4.0 \%$ $(p=0.001)$ and $91.7 \% \pm 2.9 \%(p=0.003)$, respectively, when fed with oac-32, ugt-26 or ugt-28 RNAi cells, compared to a viability of $97.7 \% \pm 2.5 \%(p=0.09)$ when fed with OP50 and a viability of $100 \%$ when not treated with DON at all. These data demonstrate that the suppression of oac-32, ugt-26 and ugt-28 genes reduced C. elegans' capability to resist DON toxicity, indicating the possible contribution of these genes to the detoxification mechanisms of C. elegans.

We then monitored the lifespan of the L4 worms that survived the DON treatment on NGM containing FUDR and seeded with OP50 bacteria. Worms fed with OP50 reached 50\% mortality 9.3 days after initial exposure to DON, compared to 10.5 days in the absence of DON (X-axis, Figure 5). Worms fed with oac-32, ugt-26 and ugt-28 RNAi bacteria reached $50 \%$ mortality rates at 7.4, 7.2 and 7.5 days, respectively. These data indicate that suppression of the oac-32, ugt-26 and ugt-28 genes (potentially involved in innate immunity and detoxicification) slightly decreases the lifespan of and that these genes may contribute to the ability of $C$. elegans to respond to and cope with the effects of DON toxicity. However, the small effects observed through the suppression of these genes indicates that there may be other genes whose contribution to the response to DON is more significant, or that there is redundancy in the transcriptional response to DON. 


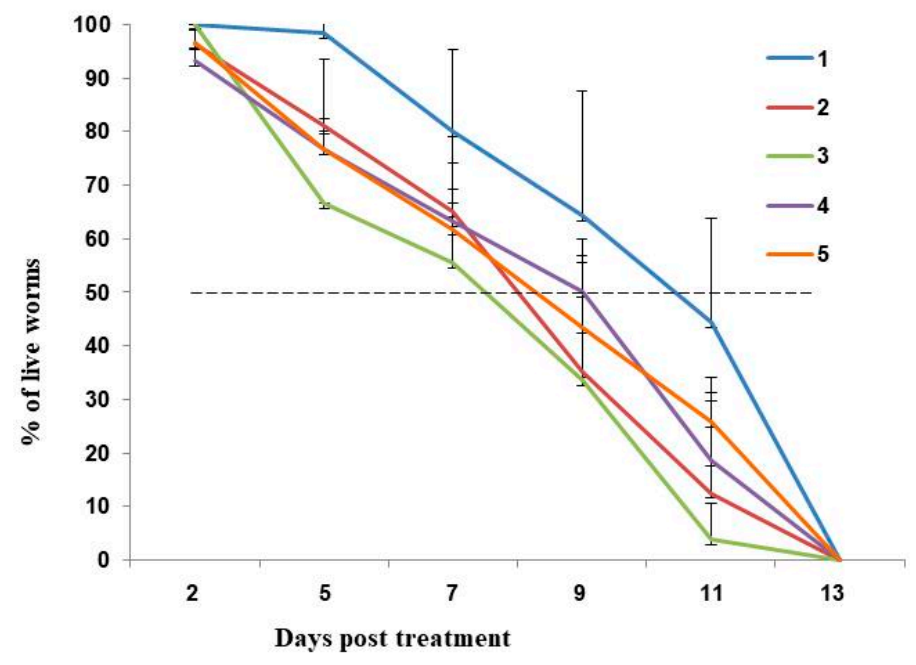

Figure 5. Lifespan analysis of worms initially fed with OP50 or oac-32, ugt-26 and ugt-28 RNAi bacteria and then treated with $250 \mu \mathrm{g} / \mathrm{mL}$ DON. After placing L4 worms on NGM medium containing 0.1 $\mathrm{mg} / \mathrm{mL}$ FUDR and OP50, the worm's viability was recorded every two days. 1, OP50; 2, DON + OP50; 3, DON + oac-32 RNAi; $4, \mathrm{DON}+u g t-26 \mathrm{RNAi} ; 5, \mathrm{DON}+u g t-28 \mathrm{RNAi}$. The results were averaged from three independent biological experiments.

\section{Discussion}

In order to better understand the molecular mechanisms of DON cytotoxicity, a trichothecene toxin present on grain crops infected with Fusarium spp., we examine global changes in DON-induced transcription in the model organism C. elegans. It has been shown by Gowrinathan et al. [12] that N2 display lower rates of development and smaller brood sizes when exposed to 500 and $100 \mu \mathrm{g} / \mathrm{mL}$ DON. In this study, we showed systematically that the N2 worms' egg-laying capability was significantly reduced by 125,250 and $500 \mu \mathrm{g} / \mathrm{mL}$ DON in a dose-dependent manner (Figure 1). We also showed that worm lifespan was reduced following exposure to $250 \mu \mathrm{g} / \mathrm{mL}$ DON, with worms requiring only 8.51 days to reach $50 \%$ mortality, compared to 11.45 days for control worms (Figure 2). Yang et al. [13] recently showed that 4 days were needed to approach $50 \%$ mortality of N2 worms exposed to $65.67 \mu \mathrm{g} / \mathrm{mL} \mathrm{DON}$, compared to the 16 days needed for control worms. However, because the developmental stage and the culture conditions used were not indicated in that report, it is not possible to compare our findings directly with this previous study.

It has been suggested that innate immunity may play a role in the molecular response of animals and humans to DON cytotoxicity [4]. It has been shown, previously, that the expression of immune effector genes C17H12.8, K08D8.5 [17] and F35E12.5 are upregulated following exposure to infection by the Shiga toxin-producing E. coli O157:H7 strain EDL933 [18]. We investigated changes in the expression of these three genes in C. elegans exposed to DON to see if they are similarly affected by DON. Our data show that all three genes are highly upregulated in a DON-dosage dependent manner (Figure 3), indicating that components of the worm's innate immunity are modulated by DON. We used RNAseq to investigate changes in the pattern of global gene expression in exposed to 250 $\mu \mathrm{g} / \mathrm{mL}$ DON.

To our knowledge, this is the first time the toxic effects of DON on C. elegans gene expression have been comprehensively investigated. Our data showed that out of $\sim 17,000$ C. elegans genes, 313 genes were upregulated and 166 genes were downregulated by DON treatment (Figure 4). The F11D11.3 gene was upregulated by 612.6-fold; interestingly, this gene is listed with no known molecular function in the WormBase (WormBase.org), suggesting that the approach adopted here of global transcriptome analysis may help identify novel components of the response to DON toxicity.

Another interesting result from our RNAseq analysis is that out of 66 ugt genes found in the WormBase, $10 \mathrm{ugt}$ genes were upregulated at least 2-fold. Of these, expression of $u g t-31$, ugt-26, 
$u g t-29$ and $u g t-28$ increased by more than 20 -fold (Table 2). The ugt genes encode uridine diphosphate (UDP)-glycosyltransferases and the encoded enzymes carry out hexosyl group transfer, a common mechanism for detoxification of xenobiotics. A superfamily of more than 100 ugt genes has been identified in the model plant Arabidopsis thaliana [20]. However, very little is known about the regulation and localization of these plant UGTs [20]. Poppenberger et al. have shown that the enzymatic reaction of Arabidopsis UGT73C5 (locus At2g36800) could inactivate DON in yeast and wheat germ, and that constitutive overexpression of this gene in Arabidopsis led to enhanced resistance against DON [21]. A later report showed that transgenic Arabidopsis plants expressing a barley ugt gene (HvUGT13248) were more resistant to DON in a seed germination assay and converted DON to DON-3-O-glucoside (D3G) to a greater extent, compared to the wild-type plants [22]. Additionally, transgenic wheat plants expressing HvUGT13248 have been shown to detoxify DON to D3G, better tolerate DON in roots and exhibit less severe disease symptoms in the field, compared to non-transformed wheat plants [23]. Together, these reports suggest that the up-regulation of ugt genes may be similarly important in DON detoxification in as they are in plants. However, the size of the ugt gene family in C. elegans and the fact that 10 members were induced by DON suggests that there may be functional redundancy.

This study has provided a comprehensive picture of the gene perturbation by DON and shed light on potential targets in plants for FHB disease resistance and in animals for developing therapeutic measures. The specificity of the response (comprising both induced and suppressed genes) indicates that it may be possible to ameliorate DON toxicity through manipulation of relatively few molecular targets. Further functional analysis of these targets, through RNAi suppression and through gene disruption experiments may prove informative, in this regard.

\section{Materials and Methods}

\subsection{Materials and Maintenance}

DON was purchased from Sigma Aldrich (St. Louis, MO, USA) and diluted in a final concentration of $0.6 \%$ DMSO for all samples tested. DMSO below $1 \%$ is generally used and has been regarded as not affecting nematode growth and development [13]. Wild-type N2 C. elegans worms were obtained from the Caenorhabditis Genetics Center (CGC, St. Paul, MN, USA). Worms were maintained on NGM with the OP50 strain of bacteria and cultured following the general protocols on the WormBook [24]. The RNAi Feeding Library was purchased from Open Biosystems Inc. (Huntsville, AL, USA).

\subsection{DON Treatment and Lifespan Studies}

Synchronized eggs were obtained from gravid worms by the bleaching method (The WormBook). L2 worms were harvested by washing them off the plate with sterile water and centrifugation at $300 \times g$ for $2 \mathrm{~min}$.

L2 worms were treated with DON at different concentrations in $0.6 \%$ DMSO in $1 \mathrm{~mL} \mathrm{S-medium}$ (The WormBook) supplemented with OP50 bacterial cells in 24-well plate at room temperature for $24 \mathrm{~h}$. After DON treatment, worms developed up to the L4 stage and were harvested by centrifugation at $300 \times g$ for $2 \mathrm{~min}$ and washed with water. For each treatment, 30 worms were placed into each well of a 24-well NGM plate supplemented with OP50 bacteria. The number of eggs laid was counted after $24 \mathrm{~h}$. Individual worms were also placed into 24-well plates supplemented with OP50 bacteria and $0.1 \mathrm{mg} / \mathrm{mL}$ FUDR (Sigma Aldrich, St. Louis, MO, USA) at 3 worms per well, totally 30 worms per treatment. The viability of worms was recorded by observation under a Nikon SMZ645 stereomicroscope and by assessing the response to mechanical stimulation. All experiments were repeated three times. The student $t$-test was used to assay the significant difference among treatments. 


\subsection{Real-Time Quantitative Polymerase Chain Reaction (RT-qPCR) Analysis of Gene Expression}

Worms at the L2 stage were treated with 125, 250 and $500 \mu \mathrm{g} / \mathrm{mL}$ DON for $24 \mathrm{~h}$ and were harvested by centrifugation and washed with water. Total RNA was isolated by the freeze/thaw method (The WormBook) using Trizol (Invitrogen, Waltham, MA, USA), and then precipitated with ethanol and resuspended in DEPC (diethyl pyrocarbonate)-treated water. The RNA concentration and quality were measured by a Nanodrop spectrophotometer (Thermo Fisher, Waltham, MA, USA). Reverse transcription (RT) reaction was carried out with the High Capacity cDNA Synthesis Kit (Applied Biosystems/Thermo Fisher, Waltham, MA, USA) using random primers. Real-time quantitative qPCR was conducted with gene-specific primers (Table 1), SYBR Green master mix and the StepOnePlus Real-time PCR System (Applied Biosystems/Thermo Fisher, Waltham, MA, USA). The actin 1 gene (T04C12.6.2) was used as the endogenous control gene. Gene expression levels, expressed as fold-changes, were assessed by the $2^{-\Delta \Delta C t}$ relative quantification method [25].

\subsection{RNAseq Analysis}

For RNAseq analysis, synchronized L1 worms were treated with either $250 \mu \mathrm{g} / \mathrm{mL}$ DON in $0.6 \%$ DMSO or $0.6 \%$ DMSO alone for $24 \mathrm{~h}$. Total RNA was isolated by the freeze-thaw method as above. Totally, $200 \mathrm{ng}$ of each RNA sample was provided to BGI (Beijing Genomics Institute, Shenzhen, China) for RNAseq analysis. mRNA was enriched on oligo $\mathrm{d}(\mathrm{T})$ magnetic beads, and the resulting cDNA library was sequenced via Illumina HiSeq ${ }^{\mathrm{TM}}$ 2000. Sequence reads were aligned to the reference genome by Soap 2.21 software. Gene function annotation was performed using BLAST (National Center for Biotechnology Information) and KEGG (Kyoto Encyclopedia of Genes and Genomes), NR (Non-Redundant) and GO (Gene Ontology) databases. Quantification of gene expression was conducted by the RPKM (reads per kilobase per million) algorithm. Pairwise comparison of gene expression levels between DON-treated and DMSO-treated samples was used to identify any differentially expressed genes (DEGs). Relative differences in gene expression difference were expressed as a log2 ratio (representing the fold-change between DON-treated and DMSO-treated samples). P-values were included for each gene. False discovery rate (FDR) $\leq 0.001$ and the absolute value of $\log 2$ Ratio $\geq 1$ were used as the threshold to judge the significance of gene expression difference [26].

\subsection{Feeding with RNAi Bacteria}

To validate the involvement of genes in the response of to DON cytotoxicity, the HT115 (DE3) E. coli cells harboring the RNAi (RNA interference) gene knock-down constructs (Open Biosystems, Huntsville, AL, USA) were used to feed C. elegans. Synchronized eggs were placed on NGM plates with bacterial lawns of OP50, and oac-32, ugt-26 and ugt-RNAi cells for $24 \mathrm{~h}$. L2 worms were washed off the plates with water and then washed with S-medium. Worms were treated with $250 \mathrm{~g} / \mathrm{mL} \mathrm{DON}$ in $1 \mathrm{~mL}$ of S-medium supplemented with OP50, and oac-32, ugt-26 or ugt-28 RNAi bacteria for $24 \mathrm{~h}$. Worms were collected and the number of dead worms was counted in three groups of 50 worms each for each treatment. The experiment was repeated three times. DON-treated and worms fed with different bacteria were then cultured on NGM plate seeded with OP50 lawn to record the lifespan of worms.

Supplementary Materials: The following are available online at http:/ /www.mdpi.com/2072-6651/10/7/262/s1, Table S1: The complete RNAseq data for all genes of C. elegans.

Author Contributions: R.D. and M.A.L. conceived and designed the experiments; R.D. performed the experiments; R.D. and M.A.L. analyzed the data; H.Z. analyzed the RNAseq data; R.D. and M.A.L. wrote and revised the paper.

Funding: USDA Multistate Fund NC1183 and Rutgers NJAES support.

Acknowledgments: We greatly appreciate the support by USDA Multistate Fund and Rutgers NJAES support awarded to M. A. Lawton. 
Conflicts of Interest: The authors declare no conflict of interest.

\section{References}

1. Di, R.; Blechl, A.; Dill-Macky, R.; Tortora, A.; Tumer, N.E. Expression of a truncated form of yeast ribosomal protein 13 in transgenic wheat improves resistance to fusarium head blight. Plant Sci. 2010, 178, 374-380. [CrossRef]

2. Wu, F.; Groopman, J.D.; Pestka, J.J. Public health impacts of foodborne mycotoxins. Annu. Rev. Food Sci. Technol. 2014, 5, 351-372. [CrossRef] [PubMed]

3. Pestka, J.J. Deoxynivalenol: Toxicity, mechanisms and animal health risks. Anim. Feed Sci. Technol. 2007, 137, 283-298. [CrossRef]

4. Pestka, J.J. Deoxynivalenol: Mechanisms of action, human exposure, and toxicological relevance. Arch. Toxicol. 2010, 84, 663-679. [CrossRef] [PubMed]

5. Pestka, J.J.; Amuzie, C.J. Tissue distribution and proinflammatory cytokine gene expression following acute oral exposure to deoxynivalenol: Comparison of weanling and adult mice. Food Chem. Toxicol. 2008, 46, 2826-2831. [CrossRef] [PubMed]

6. Nejdfors, P.; Ekelund, M.; Jeppsson, B.; Westrom, B.R. Mucosal in vitro permeability in the intestinal tract of the pig, the rat, and man: Species- and region-related differences. Scand. J. Gastroenterol. 2000, 35, 501-507. [PubMed]

7. Szelenyi, I.; Herold, H.; Gothert, M. Emesis induced in domestic pigs: A new experimental tool for detection of antiemetic drugs and for evaluation of emetogenic potential of new anticancer agents. J. Pharmacol. Toxicol. Methods 1994, 32, 109-116. [CrossRef]

8. Brenner, S. The genetics of dcaenorhabditis elegans. Genetics 1974, 77, 71-94. [PubMed]

9. Anderson, G.L.; Boyd, W.A.; Williams, P.L. Assessment of sublethal endpoints for toxicity testing with the nematode caenorhabditis elegans. Environ. Toxicol. Chem. 2001, 20, 833-838. [CrossRef] [PubMed]

10. Leung, M.C.; Williams, P.L.; Benedetto, A.; Au, C.; Helmcke, K.J.; Aschner, M.; Meyer, J.N. Caenorhabditis elegans: An emerging model in biomedical and environmental toxicology. Toxicol. Sci. 2008, 106, 5-28. [CrossRef] [PubMed]

11. Boyd, W.A.; McBride, S.J.; Rice, J.R.; Snyder, D.W.; Freedman, J.H. A high-throughput method for assessing chemical toxicity using a caenorhabditis elegans reproduction assay. Toxicol. Appl. Pharmacol. 2010, 245, 153-159. [CrossRef] [PubMed]

12. Gowrinathan, Y.; Pacan, J.C.; Hawke, A.; Zhou, T.; Sabour, P.M. Toxicity assay for deoxynivalenol using caenorhabditis elegans. Food Addit. Contam. Part A 2011, 28, 1235-1241. [CrossRef] [PubMed]

13. Yang, Z.; Xue, K.S.; Sun, X.; Tang, L.; Wang, J.S. Multi-toxic endpoints of the foodborne mycotoxins in nematode caenorhabditis elegans. Toxins 2015, 7, 5224-5235. [CrossRef] [PubMed]

14. Parmalee, N.L.; Maqbool, S.B.; Ye, B.; Calder, B.; Bowman, A.B.; Aschner, M. Rnaseq in C. elegans following manganese exposure. Curr. Protoc. Toxicol. 2015, 65. [CrossRef]

15. Bhaskar, A.S.; Gupta, N.; Rao, P.V. Transcriptomic profile of host response in mouse brain after exposure to plant toxin abrin. Toxicology 2012, 299, 33-43. [CrossRef] [PubMed]

16. Troemel, E.R.; Chu, S.W.; Reinke, V.; Lee, S.S.; Ausubel, F.M.; Kim, D.H. P38 mapk regulates expression of immune response genes and contributes to longevity in C. elegans. PLoS Genet. 2006, 2, e183. [CrossRef] [PubMed]

17. Chou, T.C.; Chiu, H.C.; Kuo, C.J.; Wu, C.M.; Syu, W.J.; Chiu, W.T.; Chen, C.S. Enterohaemorrhagic escherichia coli o157:H7 shiga-like toxin 1 is required for full pathogenicity and activation of the p38 mitogen-activated protein kinase pathway in caenorhabditis elegans. Cell. Microbiol. 2013, 15, 82-97. [CrossRef] [PubMed]

18. Jakobsen, H.; Bojer, M.S.; Marinus, M.G.; Xu, T.; Struve, C.; Krogfelt, K.A.; Lobner-Olesen, A. The alkaloid compound harmane increases the lifespan of Caenorhabditis elegans during bacterial infection, by modulating the nematode's innate immune response. PLOS ONE 2013, 8, e60519. [CrossRef] [PubMed]

19. Bock, K.W. The udp-glycosyltransferase (ugt) superfamily expressed in humans, insects and plants: Animal-plant arms-race and co-evolution. Biochem. Pharmacol. 2016, 99, 11-17. [CrossRef] [PubMed]

20. Ross, J.; Li, Y.; Lim, E.; Bowles, D.J. Higher plant glycosyltransferases. Genome Biol. 2001, 2, REVIEWS3004. [CrossRef] [PubMed] 
21. Poppenberger, B.; Berthiller, F.; Lucyshyn, D.; Sieberer, T.; Schuhmacher, R.; Krska, R.; Kuchler, K.; Glossl, J.; Luschnig, C.; Adam, G. Detoxification of the fusarium mycotoxin deoxynivalenol by a udp-glucosyltransferase from arabidopsis thaliana. J. Biol. Chem. 2003, 278, 47905-47914. [CrossRef] [PubMed]

22. Shin, S.; Torres-Acosta, J.A.; Heinen, S.J.; McCormick, S.; Lemmens, M.; Paris, M.P.; Berthiller, F.; Adam, G.; Muehlbauer, G.J. Transgenic Arabidopsis thaliana expressing a barley udp-glucosyltransferase exhibit resistance to the mycotoxin deoxynivalenol. J. Exp. Bot. 2012, 63, 4731-4740. [CrossRef] [PubMed]

23. Li, X.; Shin, S.; Heinen, S.; Dill-Macky, R.; Berthiller, F.; Nersesian, N.; Clemente, T.; McCormick, S.; Muehlbauer, G.J. Transgenic wheat expressing a barley udp-glucosyltransferase detoxifies deoxynivalenol and provides high levels of resistance to fusarium graminearum. Mol. Plant-Microbe Interact. 2015, 28, 1237-1246. [CrossRef] [PubMed]

24. WormBook. Available online: www.wormbook.org (accessed on 1 June 2018).

25. Livak, K.J.; Schmittgen, T.D. Analysis of relative gene expression data using real-time quantitative pcr and the 2(-delta delta c(t)) method. Methods 2001, 25, 402-408. [CrossRef] [PubMed]

26. Nakad, R.; Snoek, L.B.; Yang, W.; Ellendt, S.; Schneider, F.; Mohr, T.G.; Rosingh, L.; Masche, A.C.; Rosenstiel, P.C.; Dierking, K.; et al. Contrasting invertebrate immune defense behaviors caused by a single gene, the Caenorhabditis elegans neuropeptide receptor gene npr-1. BMC Genom. 2016, 17, 280-300. [CrossRef] [PubMed]

(C) 2018 by the authors. Licensee MDPI, Basel, Switzerland. This article is an open access article distributed under the terms and conditions of the Creative Commons Attribution (CC BY) license (http:/ / creativecommons.org/licenses/by/4.0/). 